\title{
Assessment of NF-kB-SN50 Effect on Adipose Tumor Necrosis Factor-alpha and Angiotensinogen Secretion and Expression
}

\author{
Lotfi S. Bin Dahman 1,2,3, , Nasser M. Al-Daghri ${ }^{1, *}$, Assim A. Alfadda ${ }^{2}$, Reem M. Sallam ${ }^{2}$ and \\ Philip G. McTernan ${ }^{1,4}$ \\ 1 Chair for Biomarkers of Chronic Diseases, Department of Biochemistry, College of Science, King Saud \\ University, Riyadh 11451, Saudi Arabia; lotfydahman@hu.edu.ye (L.S.B.). \\ 2 Obesity Research Center, College of Medicine, King Saud University, Riyadh 11461, Saudi Arabia; \\ 3 Medical Biochemistry Department, College of Medicine and Health Sciences, Hadhramout University, \\ Mukalla 50511, Yemen; lotfydahman@gmail.com (A.A.A.) \\ 4 Clinical Sciences Research Institute, University Hospitals Coventry and Warwickshire Trust, Walsgrave, \\ Coventry CV2 2DX, United Kingdom; (P.G.M.). \\ * Correspondence: aldaghri2011@gmail.com (N.M.A.). Tel.: +009-661-467-5939; Fax: +009-661-467-5931. \\ + Presented at the 1st International Electronic Conference on Biomolecules: Natural and Bio-Inspired \\ Therapeutics for Human Diseases, 1-13 December 2020; Available online: https://iecbm2020.sciforum.net/.
}

Received: date; Accepted: date; Published: date

\begin{abstract}
Central adiposity is one of the significant determinants of obesity-related hypertension risk, which may arise due to the pathogenic inflammatory nature of the abdominal fat depot. Proinflammatory cytokines and adipokines upregulation through nuclear factor-kappa B (NF-kB) activation in adipose tissue has been considered to have an important function in the pathogenesis of obesity-related hypertension. This study was aimed to ascertain the effect of NF-kB inhibitor, (SN50) on TNF- $\alpha$ and AGT secretion and expression in mediating the anti-inflammatory effect through its effects on NF- $\kappa \mathrm{B}$ activity in human adipose tissue. Primary human adipocytes were isolated from 20 subjects among 10 overweight and 10 obese with and without hypertension and

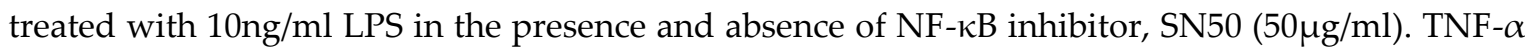
secretion and NF- $\kappa B$ p65 activity were detected in supernatants extracted from cultured cells treated, and untreated with LPS $(10 \mathrm{ng} / \mathrm{ml})$, and SN50 $(50 \mu \mathrm{g} / \mathrm{ml})$ using ELISA. The protein of NF$\kappa B$ p65 and AGT was detected by the western blot technique. Gene expression of TNF- $\alpha$ and AGT was detected in cells and performed using quantitative RT-PCR. Treatment of AbdSc adipocytes with LPS $(10 \mathrm{ng} / \mathrm{ml})$ caused a significant increase in NF-kB p65 in overweight and obese subjects with and without hypertension $(P=0.001)$ at 24 hours incubation, while, SN50-NF-kB inhibitor causes a reduction of NF-kB p65 in overweight $(P=<0.001)$ and obese subjects with and without hypertension $(P=0.001)$ at 24 hours incubation. Treatment of AbdSc adipocytes with $10 \mathrm{ng} / \mathrm{ml}$ LPS caused a significant increase in TNF- $\alpha$ secretion in overweight and obese subjects at all time points $(P=<0.001)$, whereas, SN50 leads to a decrease in TNF- $\alpha$ secretion at 3 and 12 hours incubation. Treatment of AbdSc adipocytes with LPS $(10 \mathrm{ng} / \mathrm{ml})$ caused increased TNF- $\alpha$ and AGT gene expression twofold compared with untreated cells, whereas, in the presence of SN50, it reduces mRNA AGT levels in both groups. Taken together these adipokines with NF- $\kappa B$ activation may represent important biomarkers to evaluate hypertension risk, as well as provide insight into the pathogenesis of obesity-related hypertension.
\end{abstract}

Keywords: abdominal subcutaneous adipocytes; angiotensinogen; nuclear factor-kappa B; lipopolysaccharide; tumor necrosis factor-alpha. 


\section{Introduction}

Abdominal adipose tissue is considered to be particularly pathogenic in nature with increasing obesity [1]. Adipose tissue is an endocrine organ that secretes numerous bioactive peptides often referred to as "adipocytokines", which have been proposed to participate in the development of hypertension [2]. From a basic physiological perspective, adipose tissue growth is tightly coupled to angiogenesis and microcirculation development. Tumor necrosis factor-alpha (TNF- $\alpha$ ) is known to regulate AGT in hepatocytes, as the AGT promoter contains a cytokine-inducible enhancer known as the acute phase response element [3].

Since pro-inflammatory adipocytokines secretion from adipose tissue is coordinated through the transcription factor: nuclear factor-kappa B (NF- $\kappa \mathrm{B})$ activation [4], which regulates the transcription of genes involved in inflammatory responses, cell growth control, and apoptosis. Thus, additional pathways in the development of hypertension may emanate from NF- $\kappa$ B activation. In resting cells, $\mathrm{NF}-\kappa \mathrm{B}$ is bound to its inhibitors I Kappa B $(\mathrm{I} \kappa \mathrm{B})$, which prevent NF- $\kappa \mathrm{B}$ from entering the nucleus.

Extracellular stimuli such as pro-inflammatory cytokines, chemokines, lipopolysaccharides (LPS) activate a set of proteins termed I $\kappa$ B kinases (IKKs), which phosphorylate I $\kappa$ B leading to an altered conformation of $\mathrm{I} \kappa \mathrm{B}$, which releases $\mathrm{NF}-\kappa \mathrm{B}$ to enter the nucleus and activates transcription of target genes [5]. Lipopolysaccharides increase the secretion of cytokines such as TNF- $\alpha$ via NF- $\kappa B$ activation [6]. TNF- $\alpha$ also induces the transcription of AGT via NF- $\kappa B$ [7]. Moreover, there is accumulating evidence that indicates ANG II is capable of inducing an inflammatory response in the cardiac tissue through the activation of NF- $\kappa \mathrm{B}[8]$.

However, the study of NF- $\mathrm{BB}$ has to some extent, been hampered by the lack of selective and specific inhibitory compounds. Our study, therefore, investigated the role of a cell-permeable peptide; SN50 as an NF- $\kappa B$ inhibitor. This peptide consisting of the nuclear localization sequence of NF- $\kappa B$ subunit ( 550 ) fused with the hydrophobic region of the signal sequence of Kaposi's fibroblast growth factor. Lin et al. [9] demonstrated that SN50 is capable of inhibiting the nuclear import of NF$\kappa \mathrm{B}$ in human monocytic cells and murine endothelial cells stimulated with LPS and TNF- $\alpha$.

The study was hypothesized that the activation of NF- $\kappa \mathrm{B}$, and the subsequent secretion, and expression of TNF- $\alpha$, and AGT from human adipose tissue may play an important role in the development of arterial hypertension in obese subjects. The results may enable us to understand the role of various pro-inflammatory agents upregulated by activated NF- $\kappa \mathrm{B}$ in the development of arterial hypertension. Our study was aimed to ascertain the effect of the NF- $\mathrm{B}$ inhibitor, SN50, on reducing TNF- $\alpha$ and AGT secretion and expression in mediating the anti-inflammatory effect through its effects on the NF- $\kappa B$ inflammatory pathway in human adipose tissue.

\section{Materials and Methods}

\subsection{Subjects and adipose tissue}

Abdominal subcutaneous adipose tissue (AbdScAT) samples were obtained from 10 overweight (Mean age: 30.71 \pm 9.69 ; and a mean BMI: 27.92 \pm 0.66 ), and 10 obese with and without hypertension

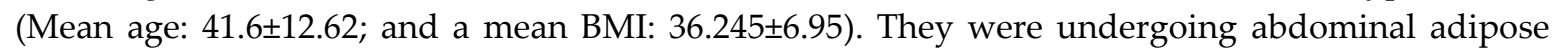
tissue liposuction for cosmetic reasons. No subject was taken on any regular medication. Subjects with chronic debilitating diseases were excluded from the study. All subjects gave their informed consent. Personal information and anthropometric measurements were taken from each subject. The previous history of diabetes, hypertension, and/or any risk factor was mentioned. All subjects fasted overnight before surgery, and only normal saline was administered intravenously until the tissue liposuction was taken. The study was carried out at the Chair for Biomarkers of Chronic Diseases and Obesity Research Center, King Saud University, Riyadh, KSA. Ethical approval was granted by the Ethics Committee of the King Khalid University Hospital, College of Medicine, King Saud University, Riyadh, KSA.

\subsection{Isolation and Culture of Mature Adipocytes}


Adipose tissue liposuction samples were digested for 30 minutes at $37^{\circ} \mathrm{C}$ in HBSS containing $2 \mathrm{mg} / \mathrm{ml}$ collagenase under intermittent shaking as described by [10]. The mixture was then centrifuged at $2000 \mathrm{rpm}$ for 5 minutes at room temperature. After centrifugation, the tubes were tilted allowing the densely packed adipocytes layer (cake of fat cell) to flow gently into a clean falcon tube. Mature fat cells were then washed by pouring in 10-15 ml of DMEM F-12 phenol-red free $(1 \mathrm{ml}$ containing $15 \mathrm{mmol} / \mathrm{l}$ glucose, supplemented with $100 \mathrm{U} / \mathrm{ml}$ of penicillin and $100 \mu \mathrm{g} / \mathrm{ml}$ streptomycin. Fat cells were centrifuged at $1000 \mathrm{rpm}$ for $1 \mathrm{~min}$. Once the adipocytes have been washed, the liquid was removed from beneath and the cake was collected into a new falcon tube. Following isolation of these cells. Cells $(0.2 \mathrm{ml}, 100,000$ adipocytes) were plated in 6-well tissue culture plates with culture medium $(1 \mathrm{ml}$, containing $15 \mathrm{mmol} / \mathrm{l}$ glucose, supplemented with $100 \mathrm{U} / \mathrm{ml}$ of penicillin, $100 \mu \mathrm{g} / \mathrm{ml}$ streptomycin, and $100 \mu \mathrm{g} / \mathrm{ml}$ transferrin). The cells were preincubated with SN50, and SN50M peptides $(50 \mu \mathrm{g} / \mathrm{ml})$ before the initiation of stimulation to enable efficient membrane translocation at $37^{\circ} \mathrm{C}$ in $95 \%$ air and $5 \% \mathrm{CO}_{2}$ for 2 hours. After preincubation, the cells were treated with $10 \mathrm{ng} / \mathrm{ml} \mathrm{LPS}$ for $03,12,24$, and 48 hours before the experiments. Initial experiments were undertaken to evaluate

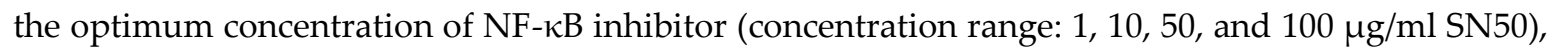
and LPS (concentration range: 1,10 , and $100 \mathrm{ng} / \mathrm{ml}$ ) without causing cellular death; this were deemed

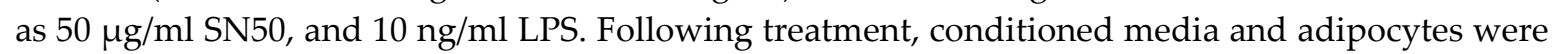
separated by centrifugation at $1000 \mathrm{rpm}$ for 1 minute. After centrifugation, the infranatant was separated and stored at $-80^{\circ} \mathrm{C}$ until adipokines measurement, whereas fat cells were used for protein expression (NF-kB p65 activity assay and western blot) and gene expression of TNF- $\alpha$ and ANG.

\subsection{NF-אB p65 Activity Assay}

NF- $\kappa B$ p65 activity was assessed using the transcription factor assay kit according to the manufacturer's instructions (TransAM NF- $\mathrm{kB}$ p65 kit, Active Motif, Rixenart, Belgium; Cat. No. 40096), as described by [11]. In brief, $20 \mu \mathrm{g}$ of total protein was used to detect NF-kB p65 activity. Jurkat cell nuclear extract $(2.5 \mu \mathrm{g})$ was used as a positive control for NF-kB p65 activation. This extract is optimized to give a strong signal when used at $2.5 \mu \mathrm{g} / \mathrm{well}$. Wild-type consensus oligonucleotides were used in the assay as a competitor for NF- $\mathrm{BB}$ binding to monitor the specificity of the assay. 20 $\mathrm{pmol} /$ well of oligonucleotides used were enough to prevent NF- $\mathrm{kB}$ binding to the probe immobilized on the plate. Conversely, the mutated consensus oligonucleotides were used as an uncompetitor for NF- $\kappa B$ binding.

\subsection{Isolation and Protein Quantification}

Total protein was quantified using Bradford DC (Detergent Compatible) protein assay kit (BioRad, USA, Cat. No. 500-0111) as described by Bradford [12]. Equal amounts of protein from each sample $(20 \mu \mathrm{g})$ and prestained markers were heated for $5 \mathrm{~min}$ at $95^{\circ} \mathrm{C}$ in loading sample buffer, loaded, and separated by $12 \%$ Sodium Dodecyl Sulphate-Polyacrylamide; SDS-PAGE running gel, and 4\% SDS-PAGE stacking gel. Gels were run for 2 hours at 120 voltages, and then blotted, and transferred onto PVDF membrane for 25 minutes at 15 voltages using a liquid transfer system. After transfer, the membrane was washed with 1X TBS for 5 minutes. The membrane was blocked for 1 hour at room temperature in a blocking buffer containing TBS with $0.1 \%$ Tween $20,5 \%$ nonfat dried milk, and $1 \%$ BSA. The membrane was then incubated with gentle agitation overnight at $4^{\circ} \mathrm{C}$ with antibodies against the following: polyclonal rabbit IgG NF-kB p65 (1:1000) (Cell Signaling Technology), polyclonal rabbit IgG angiotensinogen (1:200) (Phoenix Pharmaceuticals Industries, USA), polyclonal goat IgG TNF- $\alpha$ (1:1000) (R\&D Systems, USA). After incubation, the membrane was then washed three times with TBS/T for 5 minutes each wash. The membrane was incubated then with the appropriate HRP-conjugated secondary antibody with gentle agitation for one hour and washed five times for 5 minutes with TBS/T. The membrane was incubated with chemiluminescent development (luminol and peroxide substrate) with gentle agitation for 1 minute in a dark room, and the membrane was drained, wrapped in plastic wrap, and exposed on the $x$-ray image.

\subsection{Isolation and Purification of Total RNA}


Cells from 6 wells were extracted with $200 \mu$ of RNA later (for RNA stabilization). Total RNA was isolated using the RNeasy mini kit according to the manufacturer's instructions (Qiagen, $\mathrm{GmBH}$, Hilden; Germany). RNA concentration and purity were performed using the Nanodrop ND-1000 spectrophotometer, USA.

\section{7. cDNA Synthesis}

The reverse transcription step was conducted on 200ng RNA using the quantitect reverse transcription kit (Qiagen, California; USA) as described by Heller et al. [13]. In brief, purified RNA samples $(200 \mathrm{ng} / \mu \mathrm{l})$ were incubated with $2 \mu \mathrm{l}$ of genomic DNA wipeout buffer at $42^{\circ} \mathrm{C}$ for 2 minutes to effectively remove contaminating genomic DNA. After genomic DNA elimination, the RNA samples were reverse transcribed using a master mix prepared from quantiscript reverse transcriptase $(1 \mu \mathrm{l})$, RT primer mix $(1 \mu \mathrm{l})$, quantiscript RT buffer $(4 \mu \mathrm{l})$ at $42^{\circ} \mathrm{C}$ for 15 minutes.

\subsection{Quantitative Real-time PCR}

All the experiments were performed in 96 well plates with CFX 96- Real-Time PCR detection system (Bio-Rad, California, USA) using a premade TaqMan probe for (AGT: Hs01586213_m1 and TNF- $\alpha$ Hs00174128_m1). Real-time relative expression experiments were performed according to the manufacturer's instructions. In brief, $1 \mu \mathrm{l}$ cDNA was used in a final PCR volume of $20 \mu \mathrm{l}$, containing $10 \mu \mathrm{l}$ of the TaqMan Master Mix (AB Applied Biosystems, Warrington, UK), $8 \mu \mathrm{l}$ RNA-free water, and $1 \mu \mathrm{l}$ TaqMan probe. Polymerase chain reaction cycles were as follows: 10 minutes at $42^{\circ} \mathrm{C}$ followed by 40 cycles for 15 seconds at $95^{\circ} \mathrm{C}$, and 1 minute at $60^{\circ} \mathrm{C}$. All reactions were multiplexed with the housekeeping gene human $18 \mathrm{~S}$ ribosomal RNA (AB Applied Biosystems, Warrington, UK), and was used as a reference, enabling data to be expressed as delta cycle threshold $(\triangle \mathrm{CT})$ values (where $\Delta \mathrm{CT}=\mathrm{CT}$ 18s- $\mathrm{CT}$ gene of interest). Quantification of target mRNA was carried out by comparison of the number of cycles required reaching the reference and target threshold values ( $\triangle \Delta C T$ method). Reactions were performed in triplicate for each sample. All statistics were performed at the $\Delta \mathrm{CT}$ stage to exclude potential bias due to the averaging of data transformed through a $2-\Delta \Delta C T$ equation.

\subsection{Statistical Analysis}

Data were analyzed using SPSS for Windows Statistical Package for Social Sciences (Version 16.0 SPSS Inc., Chicago, IL, USA). Data are expressed as mean \pm standard error (SE) Independent sample ttest was done for delta $C T(\Delta C T)$ among untreated and various treatment groups. $P<0.05$ was considered as a significant value.

\section{Results}

\subsection{Inhibitory Effect of SN50 on NF-kB Translocation and Activity in Cultured Human AbdSc Adipocytes}

Figure 1 show the effect of SN50 on NF- $\mathrm{BB}$ translocation and activity in untreated and LPStreated cells taken from overweight, and obese with and without hypertension at different time points. Treatment of adipocytes with $10 \mathrm{ng} / \mathrm{ml}$ LPS, resulted a significant increase in NF- $\kappa B$ activity in obese with and without hypertension than overweight subjects at 3 and 12 hours respectively (Controls: $0.32 \pm 0.06$ vs. LPS: $0.54 \pm 0.06 ; P=0.005 ; 0.34 \pm 0.02$ vs. $0.57 \pm 0.04 ; P=0.001$ ), and a significant increase in both groups at 24 hours (overweight: controls: $0.21 \pm 0.07$ vs. LPS: $0.46 \pm 0.02 ; P=0.002$; obese subjects with or without hypertension: controls: $0.33 \pm 0.04$ vs. $0.54 \pm 0.04 ; P=0.005$ ) Coincubation with SN50 $(50 \mu \mathrm{g} / \mathrm{ml})$ effectively abrogated LPS-stimulated NF- $\kappa B$ activity in the obese subjects with or without hypertension at 3,12 , and 24 hours ( 3 h, LPS: $0.54 \pm 0.06$ vs. SN50+LPS: $0.35 \pm 0.06 ; P=0.01 ; 12$ h, LPS: $0.57 \pm 0.04$ vs. SN50+LPS: $0.31 \pm 0.05 ; P<0.001 ; 24$ h, LPS: $0.54 \pm 0.05$ vs. SN50+LPS: $0.41 \pm 0.11$; $P<0.001$ ) respectively, and in overweight subjects only at 24 hour (LPS: $0.46 \pm 0.02$ vs. SN50+LPS: 0.24 $\pm 0.03 ; P<0.001$ ). In contrast, SN50M (Inactive peptide) did not affect the ability of LPS to activate and translocate NF- $\kappa B$. Incubation with SN50 alone did not influence NF- $\kappa B$ activity in both groups (overweight: $3 \mathrm{hr}$.; controls: $0.38 \pm 0.04$ vs. SN50: $0.36 \pm 0.04 ; P=\mathrm{NS}$; obese with or without 
hypertension; 3 hr.; control: $0.32 \pm 0.06$ vs. SN50: $0.41 \pm 0.06$; $P=\mathrm{NS}$; A 12 hr.; controls: $0.33 \pm 0.07$ vs. $0.29 \pm 0.1 ; P=\mathrm{NS}$; B 12 hr.; control: $0.34 \pm 0.02$ vs. SN50: $0.29 \pm 0.04 ; P=\mathrm{NS}$; overweight, $24 \mathrm{hr}$.; controls: $0.21 \pm 0.07$ vs. SN50: $0.14 \pm 0.09 ; P=\mathrm{NS}$; obese with or without hypertension, $24 \mathrm{hr}$; controls: $0.33 \pm 0.04$ vs. SN50: $0.32 \pm 0.08 ; P=\mathrm{NS})$. Values are expressed as mean $\pm \mathrm{SE}$ using the sample student $\mathrm{t}$-test.

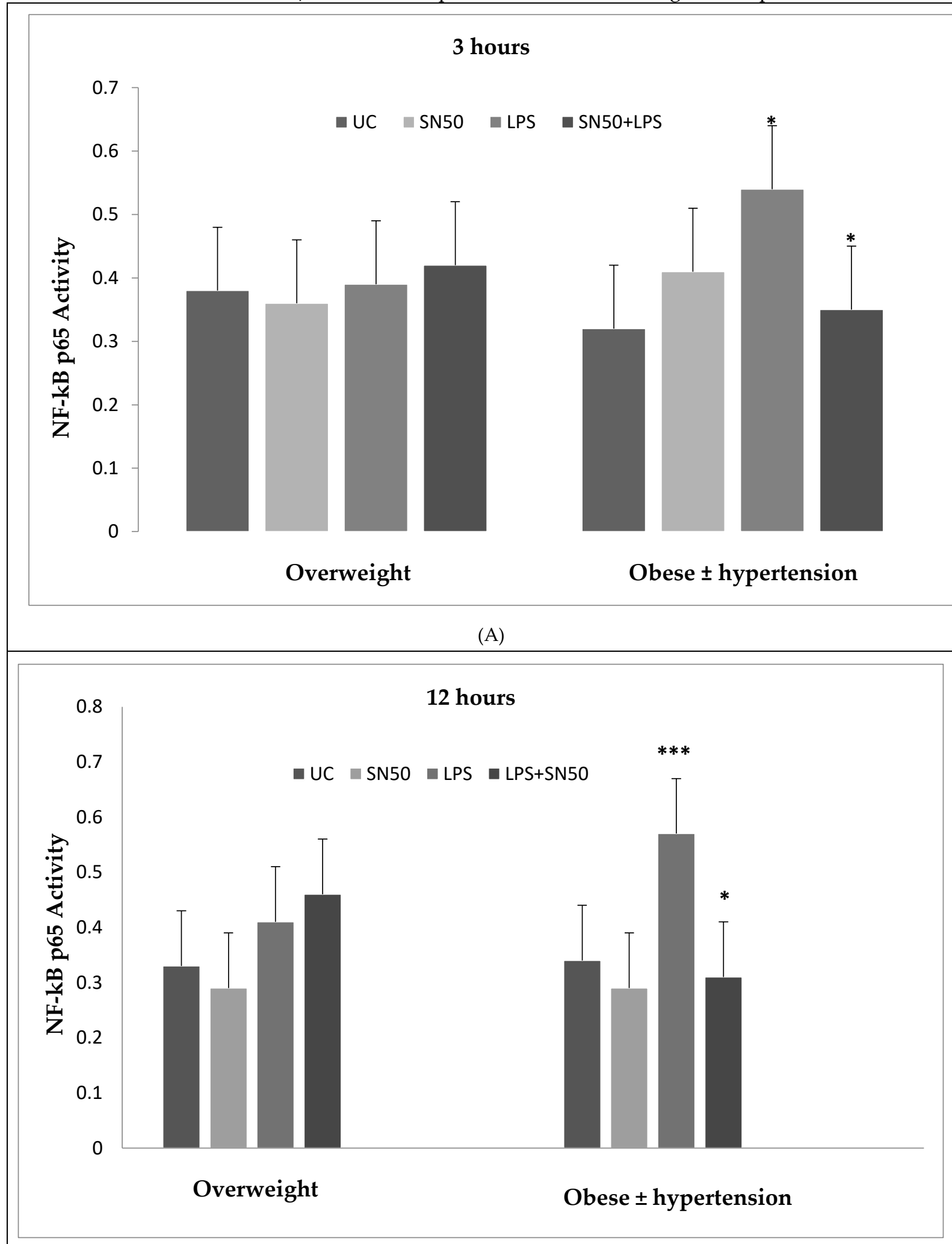

(B) 


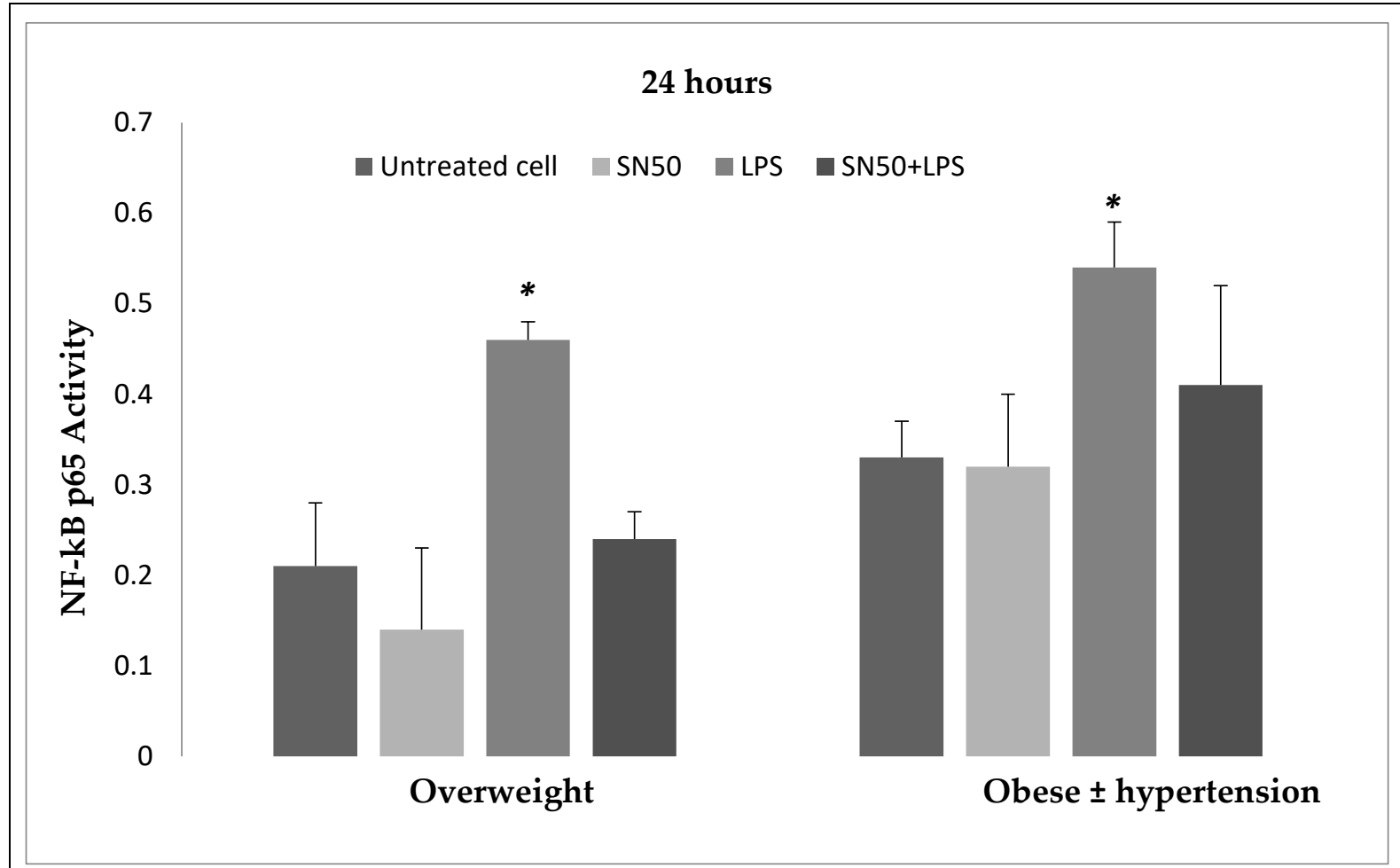

(C)

Figure 1. Inhibitory Effect of NF- $\kappa B$ Inhibitor, SN50 on NF- $\kappa B$ p 65 Activity in Human Cultured AbdSc Adipocytes. (A) Adipocytes treated with LPS $(10 \mathrm{ng} / \mathrm{ml})$ in the presence and absence of SN50 (50 $\mu \mathrm{g} / \mathrm{ml}$ ) of overweight and obese \pm hypertension at 3 hours incubation. Values are expressed as means \pm SEM using the student $t$-test. Values of $p<0.05$ were considered significant versus untreated and treated cells. ${ }^{*} \mathrm{P}$-value $=<0.05,{ }^{* *} \mathrm{P}$-value $=0.001,{ }^{* * * P}$-value $=<0.001$. Abbreviations: UC: untreated cells; LPS: lipopolysaccharides; SN50: NF-kB inhibitor. (B) Adipocytes treated with LPS (10 ng/ml) in the presence and absence of SN50 $(50 \mu \mathrm{g} / \mathrm{ml})$ of overweight and obese \pm hypertension at 12 hours incubation. Values are expressed as means \pm SEM using the student t-test. Values of $\mathrm{P}<0.05$ were considered significant versus untreated and treated cells with LPS. ${ }^{*} \mathrm{P}$-value $=<0.05,{ }^{* *} \mathrm{P}$-value $=0.001$, ${ }^{* * *} \mathrm{P}-\mathrm{value}=<0.001$. Abbreviations: UC: untreated cells; LPS: lipopolysaccharides; SN50: NF-kB inhibitor. (C) Adipocytes treated with LPS $(10 \mathrm{ng} / \mathrm{ml})$ in the presence and absence of SN50 (50 $\mu \mathrm{g} / \mathrm{ml})$ of overweight and obese \pm hypertension at 24 hours incubation. Values are expressed as means \pm SEM using the student $\mathrm{t}$-test. Values of $\mathrm{p}<0.05$ were considered significant versus untreated and treated cells. ${ }^{*}$ P-value $=<0.05,{ }^{* * P}$-value $=0.001,{ }^{* *} \mathrm{P}$-value $=<0.001$. Abbreviations: UC: untreated cells; LPS: lipopolysaccharides; SN50: NF-kB inhibitor.

\subsection{SN50 Reduces NF- $\kappa B$ p65 Protein in LPS-Stimulated Adipocytes}

To explore whether inhibition of NF- $\kappa \mathrm{B}$ p65 protein reduces LPS-stimulated adipocytes, we isolated protein from adipocytes treated with $10 \mathrm{ng} / \mathrm{ml}$ LPS for 3, 12, and 24 hours with or without SN50 $(50 \mu \mathrm{g} / \mathrm{ml})$. LPS alone increased NF- $\kappa$ B protein levels compared with those in control cells (figure 2). In contrast, Coincubation with LPS and SN50 resulted in a marked reduction of NF- $\kappa$ B p65 protein levels at 3 and 12 hours, but did not affect at 24 hours. 


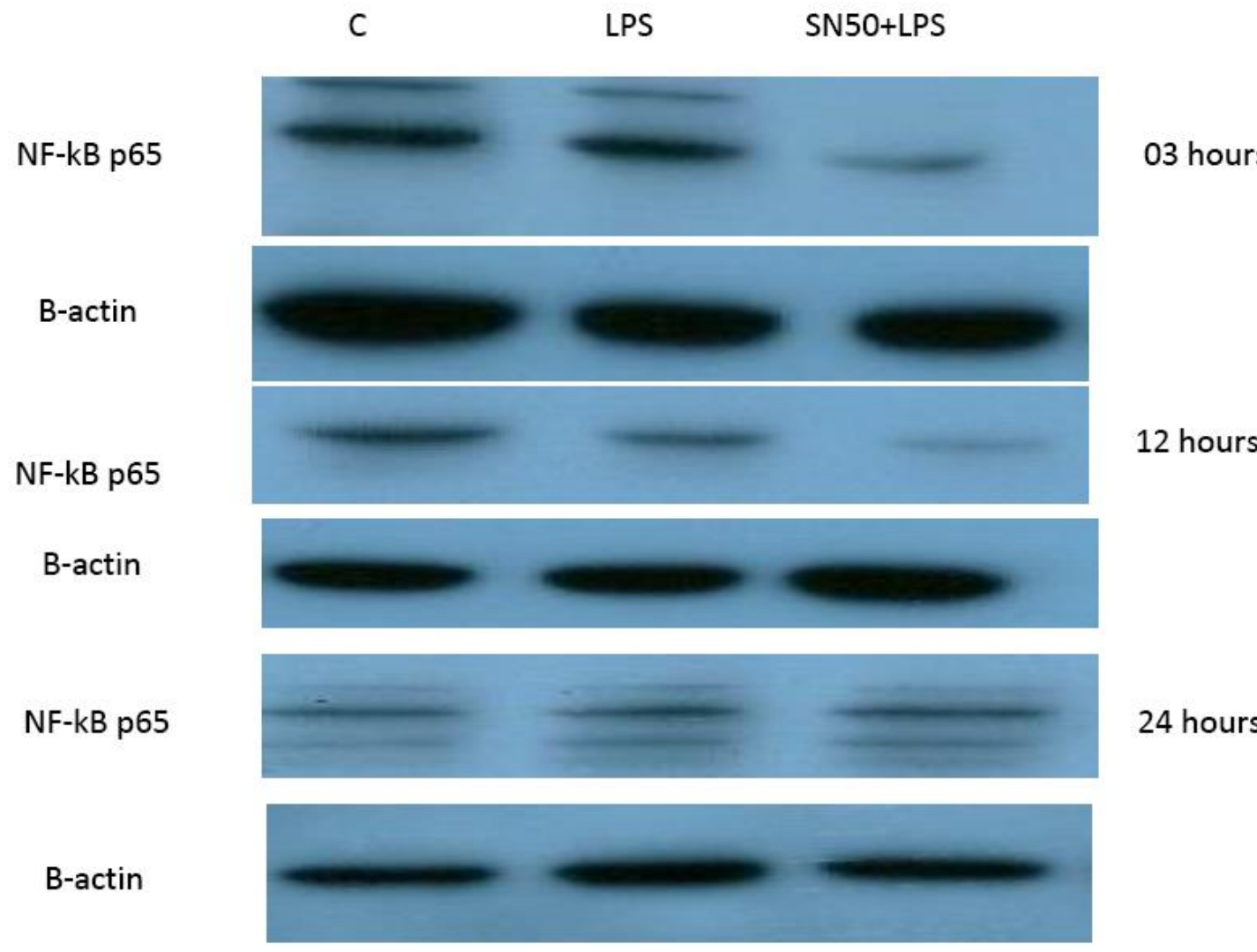

Figure 2. NF- $\kappa B$ p65 antibody. Adipocyte cells were treated with LPS at $10 \mathrm{ng} / \mathrm{ml}$ in the presence and absence of SN50 (50 $\mu \mathrm{g} / \mathrm{ml})$ at 3, 12, and 24 hours incubation. Proteins ( $20 \mu \mathrm{g}$ per lane) were separated by $12 \%$ SDS-PAGE and analyzed by western blotting using the anti-NF- $\kappa B$ p65 antibody. Loading equality was controlled using an antibody against the $\beta$-actin protein.

\subsection{LPS Induced TNF- $\alpha$ Secretion is linked to the Activation of NF-kB Pathway in Cultured Human AbdSc Adipocytes}

The role of the NF- $\kappa B$ pathway in the gene expression and secretion of TNF- $\alpha$ has been determined through the use of a specific inhibitor to this pathway; cell permeable inhibitor peptide, SN50. Figure 3 shows that the use of SN50 $(50 \mu \mathrm{g} / \mathrm{ml})$ causes a dose dependent reduction in the LPS $(10 \mathrm{ng} / \mathrm{ml})$ induced activation of TNF- $\alpha$ secretion in both groups at different time points (overweight 3 h; LPS: $31.1 \pm 3.4$ vs. SN50+LPS: $12.6 \pm 2.6 \mathrm{pg} / \mathrm{ml} ; P=0.008$; obese \pm hypertension: LPS: $82.2 \pm 4$ vs. SN50+LPS: $54.4 \pm 3.1 \mathrm{pg} / \mathrm{ml}$; $P<0.001$; overweight 12 h; LPS: $140 \pm 7$ vs. SN50+LPS: $124.7 \pm 5.1$ pg/ml; $P=0.09$; obese \pm hypertension: LPS: $177.3 \pm 6.7$ vs. SN5+LPS: $93.3 \pm 5.3 \mathrm{pg} / \mathrm{ml} ; P<0.001$; overweight 24 hr.; LPS: $80.3 \pm 4.3$ vs. SN50+LPS: $47.3 \pm 5.9$ pg/ml; $P=0.02$; obese \pm hypertension: LPS: $123.2 \pm 6.2$ vs. SN50+LPS: $59 \pm 5.2 \mathrm{pg} / \mathrm{ml} ; P<0.001$ ). The maximum inhibition of TNF- $\alpha$ secretion (around $50 \%$ ) is obtained with a concentration of $50 \mu \mathrm{g} / \mathrm{ml}$. Whereas, TNF- $\alpha$ secretion was increased in LPS-treated compared with untreated cells (controls) in both groups (overweight $3 \mathrm{~h}$; controls: $7.1 \pm 1.5 \mathrm{vs}$. LPS: $31.1 \pm 3.4 \mathrm{pg} / \mathrm{ml} ; P<0.001$; obese \pm hypertension: controls: $5.7 \pm 1.3$ vs. LPS: $82.2 \pm 4 \mathrm{pg} / \mathrm{ml} ; P<0.001$; overweight 12 hr.; controls: $2.0 \pm 0.62$ vs. LPS: $140 \pm 7$ pg/mL; $P<0.001$; obese \pm hypertension: controls: $8.1 \pm 1.2$ vs. LPS: $177.3 \pm 6.7 \mathrm{pg} / \mathrm{ml} ; P<0.001$; overweight $24 \mathrm{hr}$.; controls: $32.2 \pm 2.3$ vs. LPS: $80.3 \pm 4.3$ $\mathrm{pg} / \mathrm{mL} ; P<0.001$; obese \pm hypertension: controls: $5.9 \pm 2.1$ vs. LPS: $123.2 \pm 6.2 \mathrm{pg} / \mathrm{ml} ; P<0.001$ ). Moreover, the maximum effect of LPS was shown at 12 hours and gradually significantly decreased after 24 hours. TNF- $\alpha$ secretion was also significantly higher in obese with and without hypertension than overweight group. In contrast, there was no change observed in TNF- $\alpha$ secretion in the presence of SN50 alone compared with untreated cells in both groups (Figure 3), [(overweight $3 \mathrm{~h}$; controls: $7.1 \pm 1.5$ vs. SN50: $4.3 \pm 1.2 \mathrm{pg} / \mathrm{ml} ; P=0.16 ; 12$ hr.; controls: $2.0 \pm 0.62$ vs. SN50: $9.5 \pm 1.2 \mathrm{pg} / \mathrm{ml} ; P=\mathrm{NS}$; 24 hr.; controls: $32.2 \pm 3.2$ vs. SN50: $3.2 \pm 1.1$ pg/ml; $P<0.001$ ), (obese \pm hypertension 3 hr.; controls: 5.7 
\pm 1.3 vs. SN50: $6.0 \pm 1.1 \mathrm{pg} / \mathrm{ml} ; P=0.86 ; 12$ hr.; controls: $8.1 \pm 1.2$ vs. SN50: $7.6 \pm 1.1 \mathrm{pg} / \mathrm{ml} ; P=0.76 ; 24$ hr.; controls: $5.9 \pm 2.1$ vs. SN50: $5.4 \pm 1.5 \mathrm{pg} / \mathrm{ml} ; P=0.92)]$. Values are expressed as mean $\pm \mathrm{SE}$.

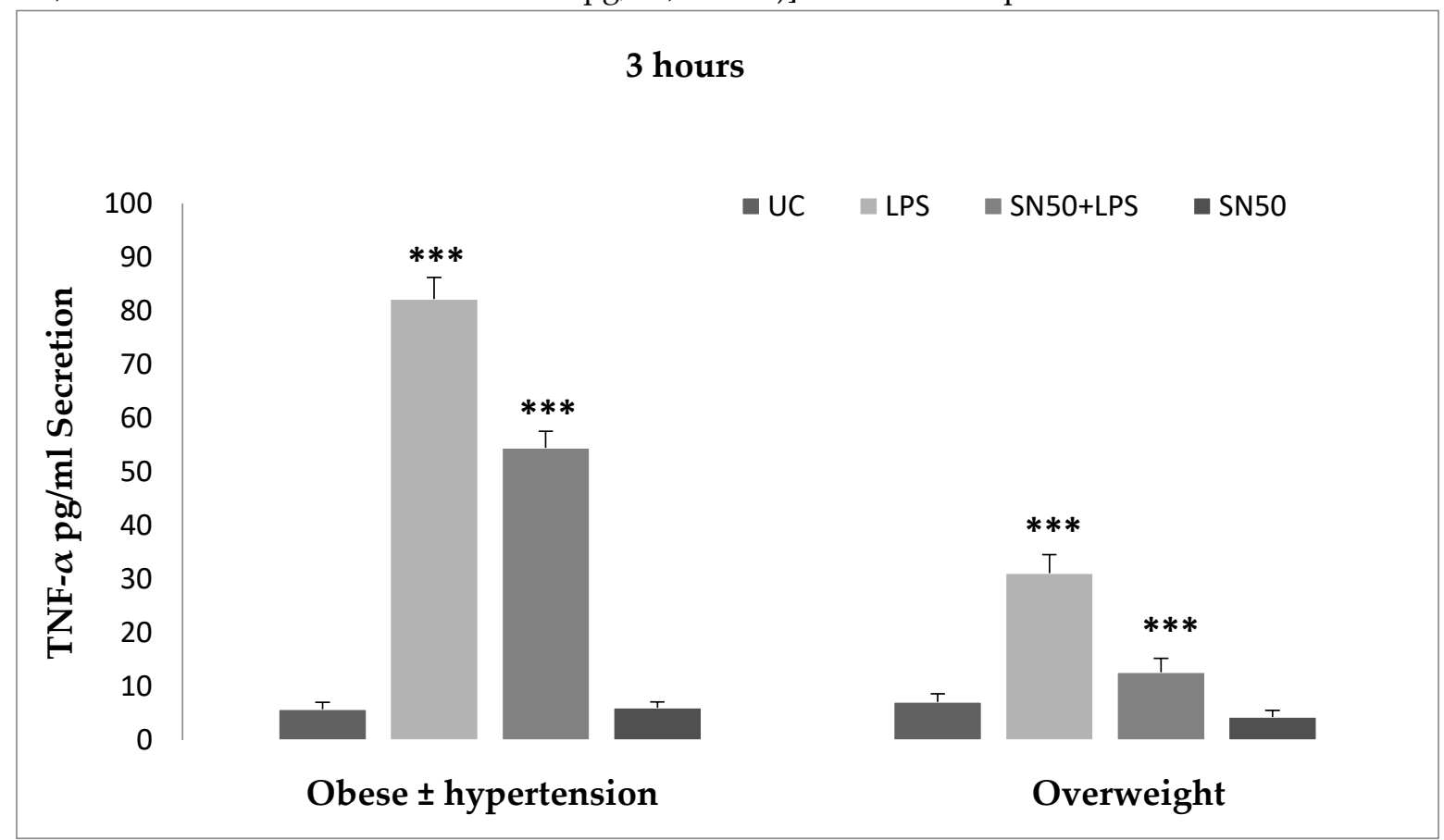

(A)

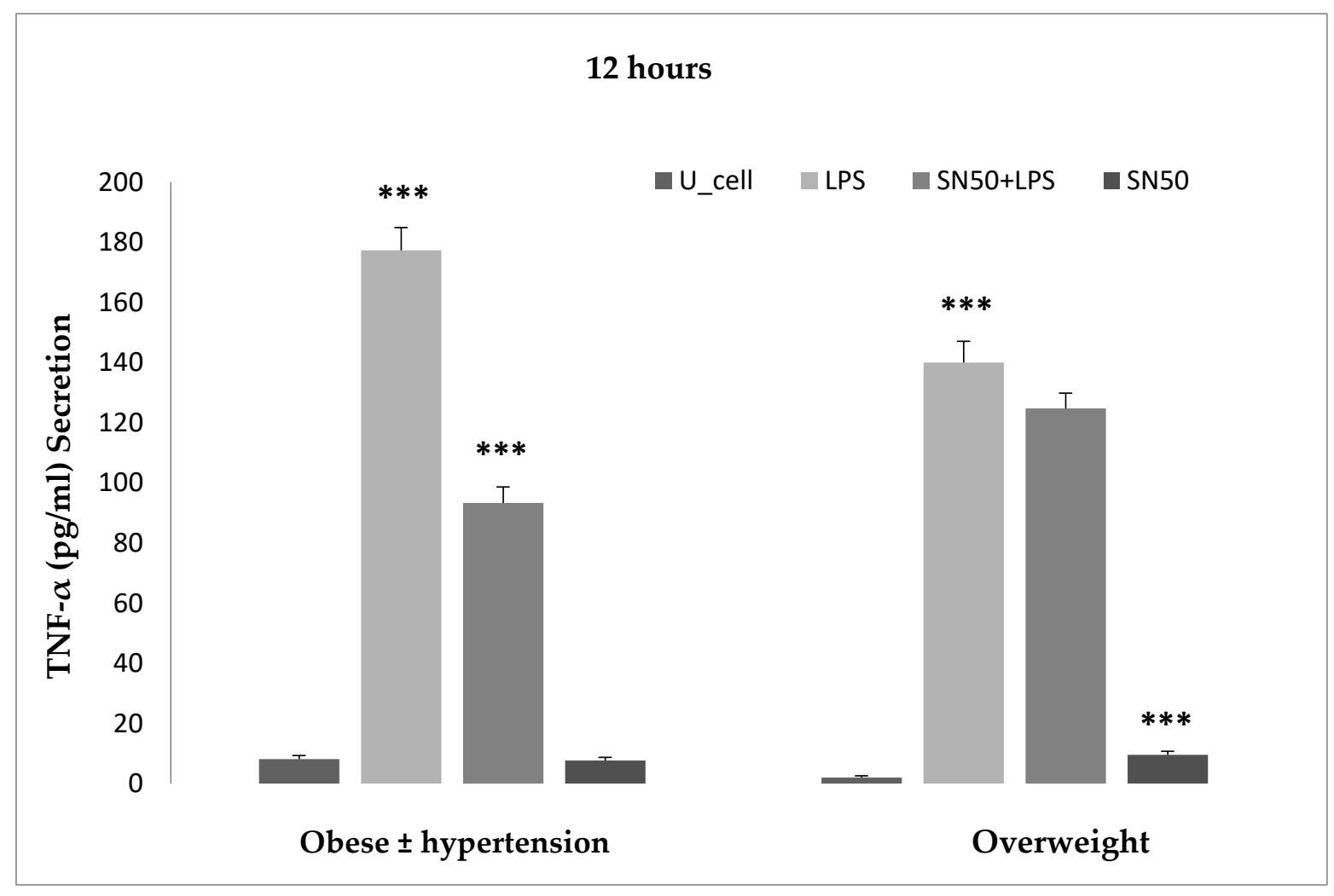

(B) 


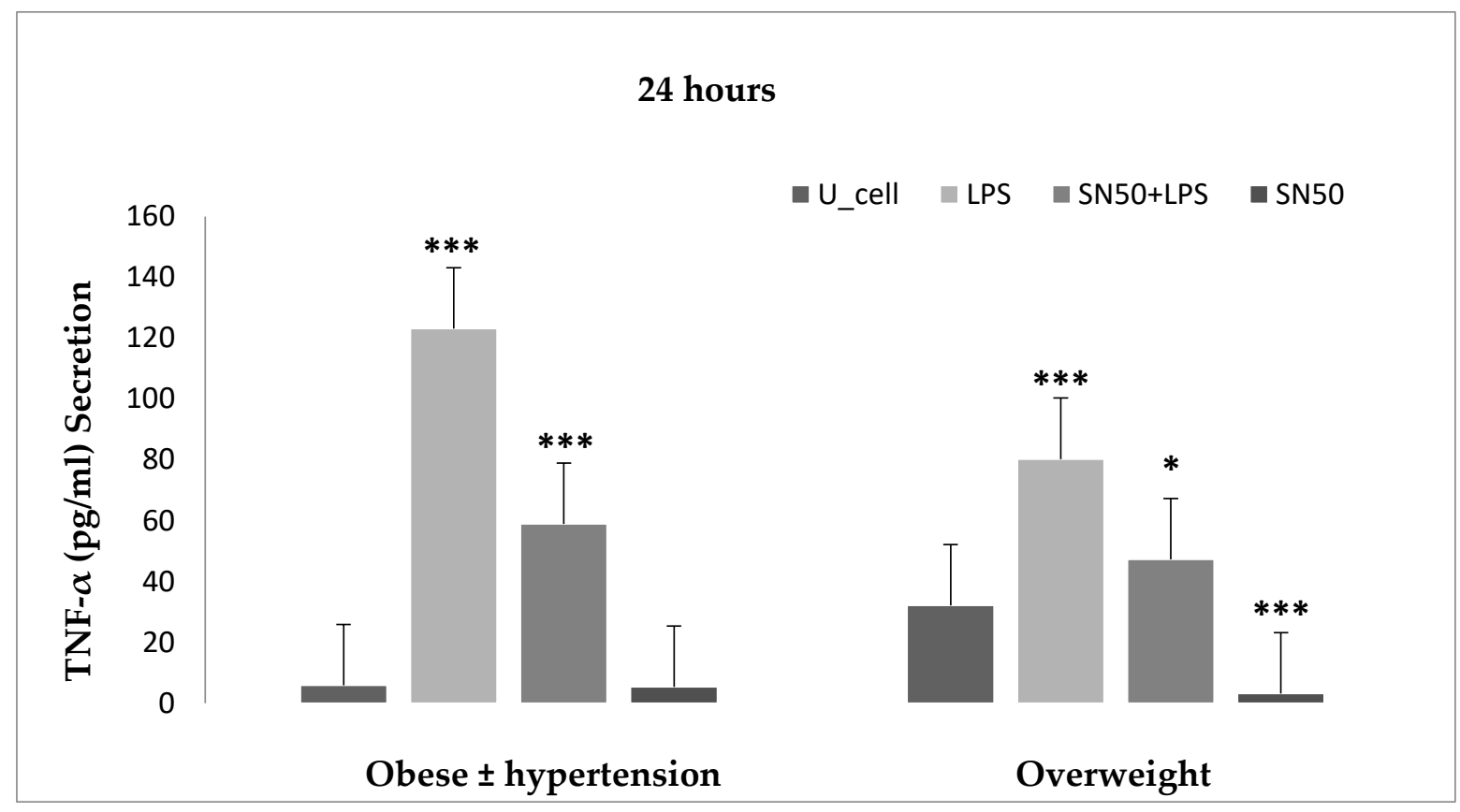

(C)

Figure 3. Secretion of TNF- $\alpha(\mathrm{pg} / \mathrm{ml})$ in Human Cultured AbdSc Adipocytes. Adipocytes treated with LPS $(10 \mathrm{ng} / \mathrm{ml})$ in the presence and absence of SN50 $(50 \mu \mathrm{g} / \mathrm{ml})$ among overweight and obese \pm hypertension at (A) 3, (B) 12 and (C) 24 hours incubation. Values are expressed as means \pm standard errors using the student $\mathrm{t}$-test. Levels of $\mathrm{P}<0.05$ were expressed a significant versus untreated cells. ${ }^{*} \mathrm{P}$-value $=<0.05,{ }^{* *} \mathrm{P}$-value $=0.001,{ }^{* * *} \mathrm{P}$-value $=<0.001$.

\section{4. mRNA Expression of TNF- $\alpha$ in Cultured Human AbdSc Adipocytes}

Figure 4 shows the mRNA TNF- $\alpha$ level in cultured human adipocytes treated with LPS and SN50 for 12 hours taken from overweight $(n=10)$, and obese with and without hypertension $(n=10)$. Treatment of AbdSc adipocytes with LPS $(10 \mathrm{ng} / \mathrm{ml})$ increased the expression of the TNF- $\alpha$ gene twofold compared with untreated cells (controls) in both groups (Controls: 1 vs. LPS: $1.87 ; P=0.005$; Controls: 1 vs. LPS: 2; $P=0.02$ ) respectively. In contrast, the treatment of AbdSc adipocytes with LPS in the presence of SN50 $(50 \mu \mathrm{g} / \mathrm{ml})$ reduced the expression of the TNF- $\alpha$ gene compared with treated cells in the overweight group (LPS: 1.87 vs. SN50+LPS: 1.15; $P=0.02$ ), whereas, no significant change was observed in the expression of TNF- $\alpha$ mRNA level in obese \pm hypertension group (LPS: 2 vs. SN50+LPS: $1.48 ; P=0.14)$. Moreover, there was no effect for SN50 alone on TNF- $\alpha$ mRNA level in both groups (controls: 1 vs. SN50: $0.88 ; P=0.51$; controls: 1 vs. SN50: $1.39 ; P=0.11$ ) respectively. No effect was also shown for inactive peptide, SN50M (data not shown). In contrast, expression of TNF- $\alpha$ gene was increased twofold in LPS-treated cell compared with controls in the combined groups studied (Figure 5), (controls: 1 vs. LPS: 1.96; $P=0.001$ ), and significantly reduced in the presence of SN50 (LPS: 1.96 vs. SN50+LPS: $1.20 ; P=0.02)$. 


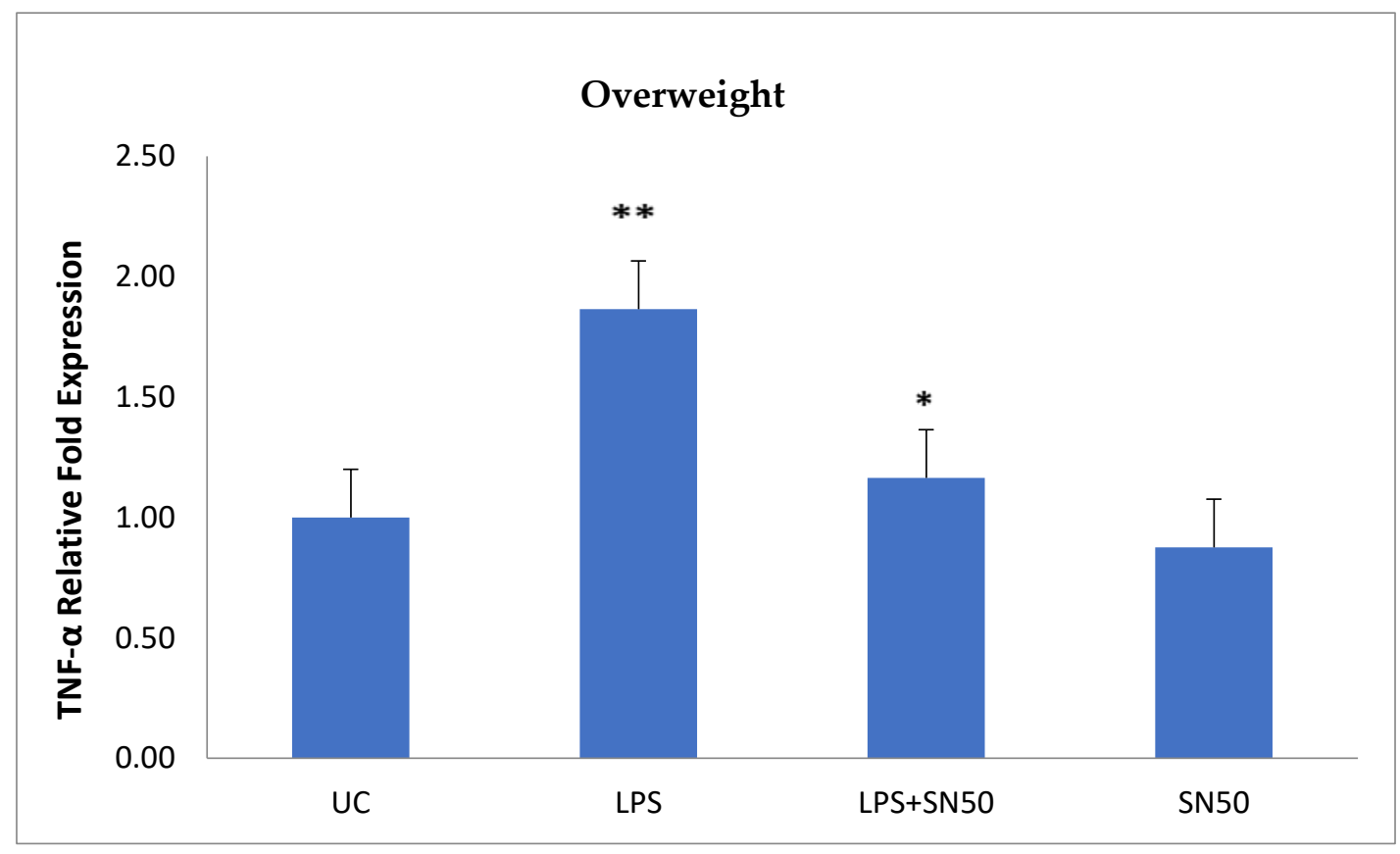

(A)

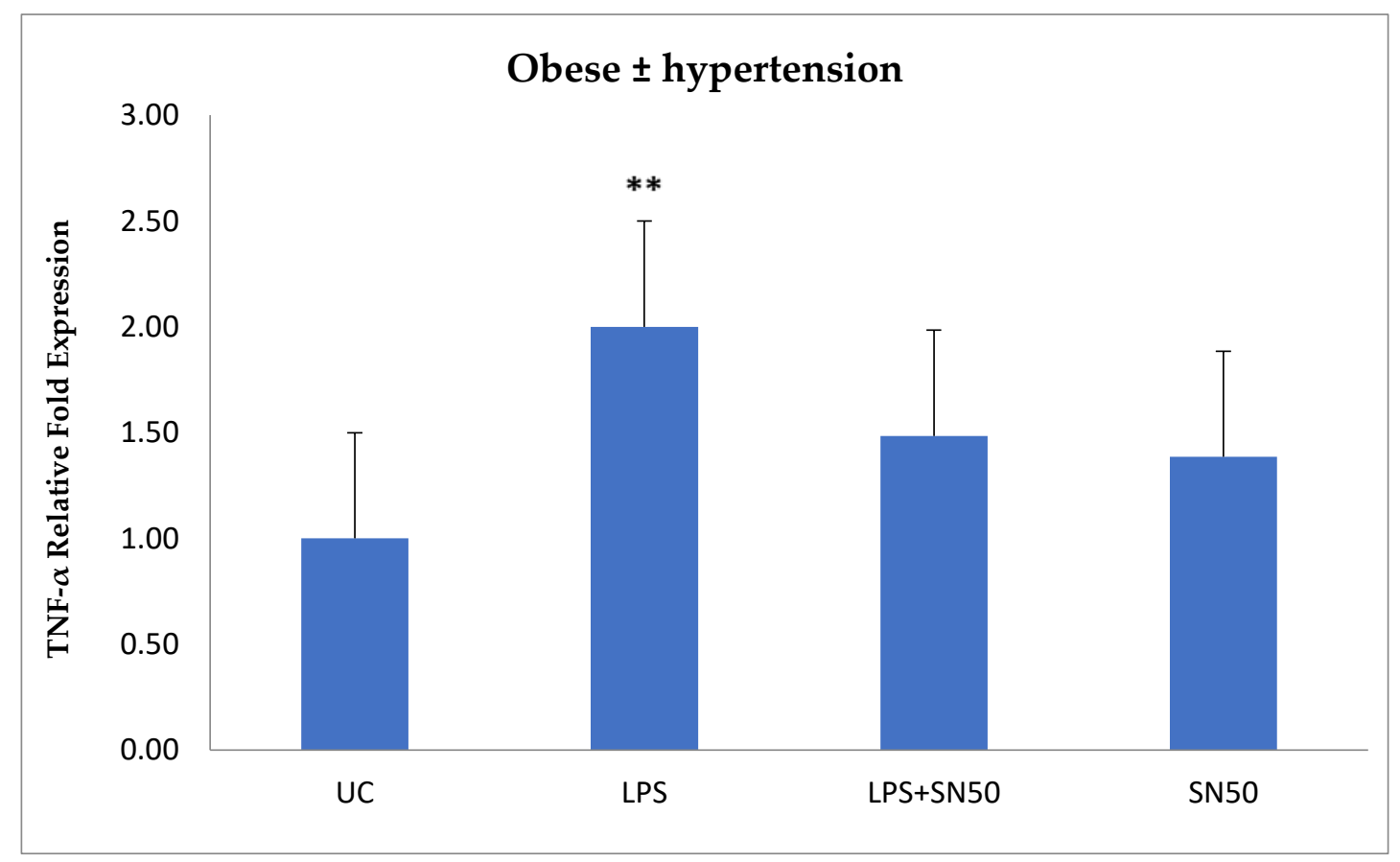

(B)

Figure 4. mRNA Expression of TNF- $\alpha$ Level among Overweight and Obese with and without Hypertension in Human Cultured AbdSc Adipocytes. Total RNA was isolated from AbdSc adipocytes from $(\mathbf{A})$ overweight $(\mathrm{n}=10)$ and $(\mathbf{B})$ obese \pm hypertension $(\mathrm{n}=10)$, treated with LPS (10 $\mathrm{ng} / \mathrm{ml})$ in the presence and absence of SN50 $(50 \mu \mathrm{g} / \mathrm{ml})$ at 12 hours incubation. Quantitative RT-PCR was performed using a premade TaqMan probe for TNF- $\alpha$. The quantitative fold changes in mRNA expression were determined as relative to $18 \mathrm{~S}$ mRNA levels in each corresponding group and calculated using the $2-\Delta \Delta^{\mathrm{CT}}$ method. Statistical analysis was undertaken using the independent sample t-test. $\mathrm{P}<0.05$ was considered a significant versus untreated cells. ${ }^{*} \mathrm{P}$-value $=0.02,{ }^{* * \mathrm{P}}$-value $=$ 0.002 (Overweight); ${ }^{* * *} \mathrm{P}$-value $=0.005$ (Obese \pm hypertension) . 


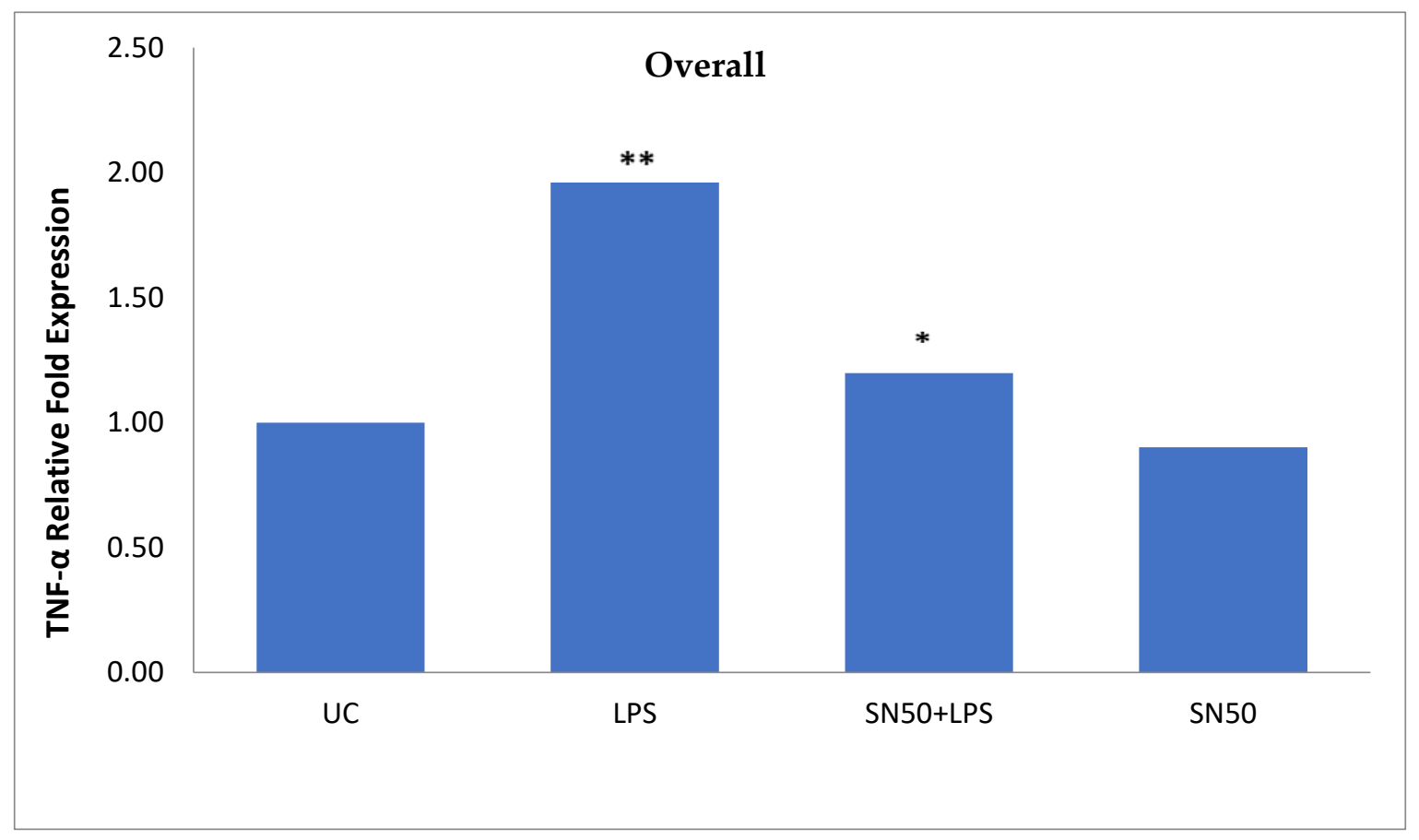

Figure 5. mRNA Expression of TNF- $\alpha$ Level in Human Cultured AbdSc Adipocytes in the Combined Group Studied. Total RNA was isolated from AbdSc adipocytes treated with LPS (10 ng/ml) in the presence and absence of SN50 $(50 \mu \mathrm{g} / \mathrm{ml})$ at 12 hours incubation. Quantitative RT-PCR was performed using a premade TaqMan probe for TNF- $\alpha$. The quantitative fold changes in mRNA expression were determined as relative to $18 \mathrm{~S}$ mRNA levels in each corresponding group and calculated using the 2$\Delta \Delta^{\mathrm{CT}}$ method. Statistical analysis was undertaken using the independent sample t-test. ${ }^{*}<0.05$ was considered a significant versus untreated cells. ${ }^{*} \mathrm{P}$-value $=<0.02,{ }^{* *} \mathrm{P}$-value $=0.001$.

\section{5. mRNA Expression of AGT in Cultured Human AbdSc Adipocytes}

Figure 6 shows mRNA AGT level in human adipocytes treated with LPS and SN50 for 12 hours taken from overweight $(n=10)$ and obese patients with and without hypertension $(n=10)$. Treatment of AbdSc adipocytes with LPS $(10 \mathrm{ng} / \mathrm{ml})$ causes an increase in the expression of AGT gene twofold compared with untreated cells (controls) in both groups (controls: 1 vs. LPS: $2 ; P=0.002$; controls: 1 vs. LPS: $2.23 ; P<0.001)$ respectively. In contrast, the treatment of AbdSc adipocytes with LPS in the presence of SN50 $(50 \mu \mathrm{g} / \mathrm{ml})$ reduced the expression of the AGT gene compared with treated cell in both groups (LPS: 2 vs. SN50+LPS: 1.23; P=0.02; LPS: 2.23 vs. SN50+LPS: 0.87; $P<0.001$ ) respectively. Moreover, there was a significant change observed in AGT mRNA level in the presence of SN50 alone in overweight and not in obese \pm hypertension group (controls: 1 vs. SN50: $0.5 ; P<0.001$; controls: 1 vs. SN50: $0.81 ; P=0.32$ ) respectively. On the other hand, the expression of the AGT gene was increased by twofold in LPS-treated cells and reduced in the presence of SN50 alone compared with untreated cells in the combined groups studied (Figure 7), (controls: 1 vs. LPS: 2.10, SN50: 0.65; $P<0.001, P=0.04$ ) respectively, and significantly reduced twofold in the presence of SN50 compared with treated cells (LPS: 2.10 vs. SN50+LPS: $1.20 ; P=0.02$ ). 


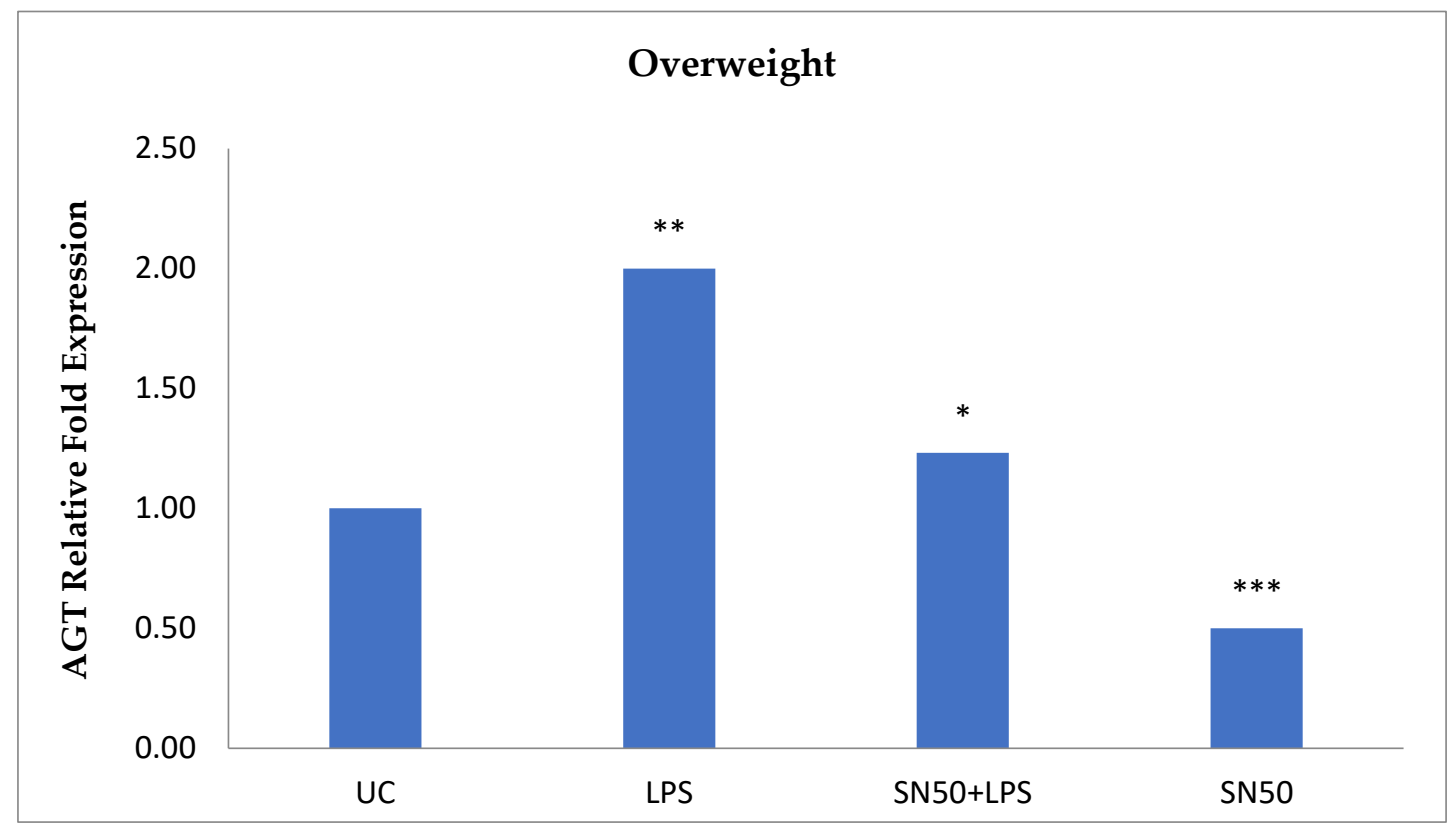

(A)

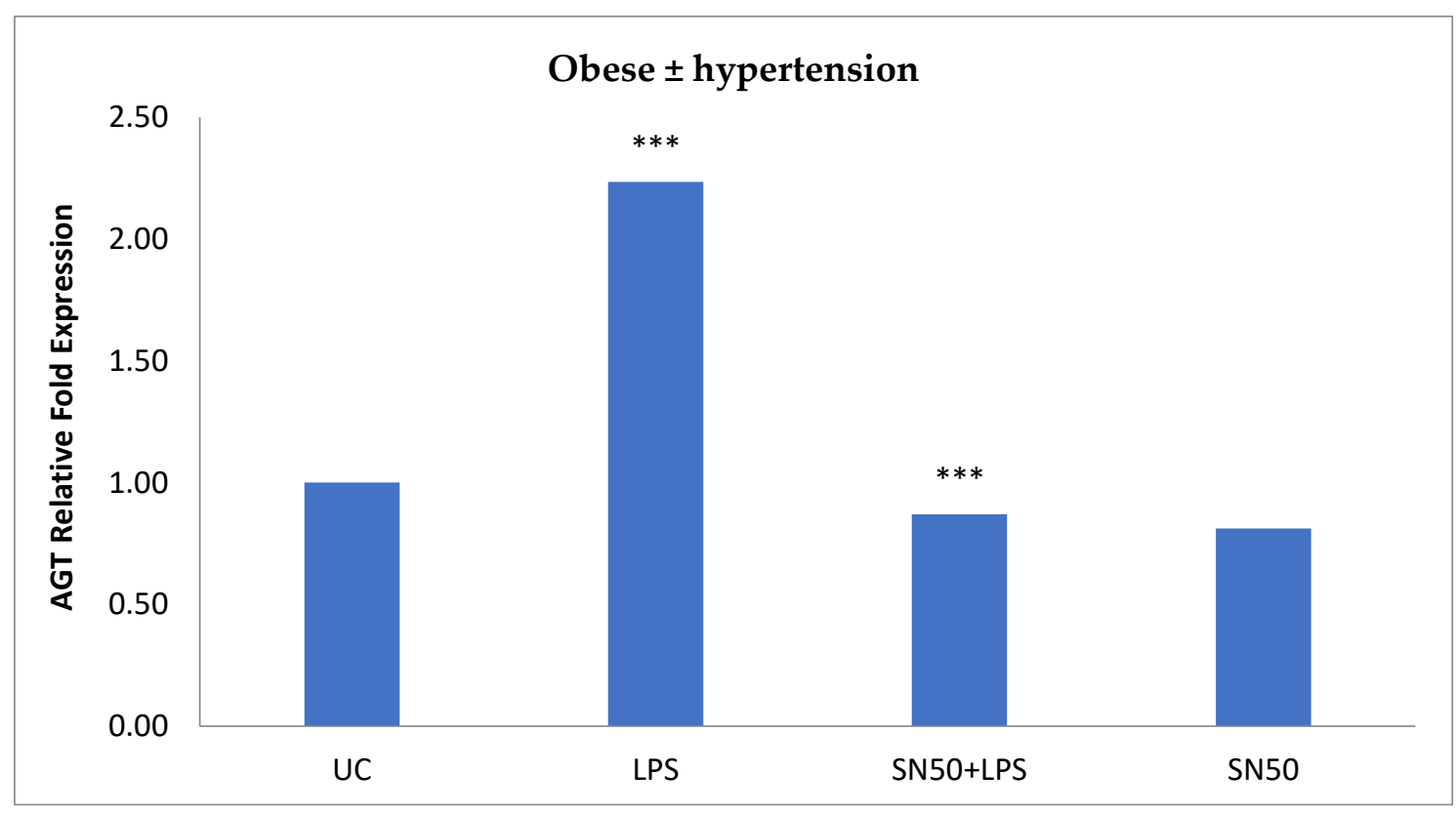

(B)

Figure 6. mRNA Expression of Angiotensinogen (AGT) Levels among Overweight and Obese with and without Hypertension in Human Cultured AbdSc Adipocytes. Total RNA was isolated from AbdSc adipocytes from $(\mathbf{A})$ overweight $(n=10)$ and $(\mathbf{B})$ obese \pm hypertension $(n=10)$ treated with LPS $(10 \mathrm{ng} / \mathrm{ml})$ in the presence and absence of SN50 $(50 \mu \mathrm{g} / \mathrm{ml})$ at 12 hours incubation. Quantitative RTPCR was performed using a premade TaqMan probe for AGT. The quantitative fold changes in mRNA expression were determined as relative to $18 \mathrm{~S}$ mRNA levels in each corresponding group and calculated using the $2-\Delta \Delta^{\mathrm{CT}}$ method. Statistical analysis was undertaken using the independent sample t-test. ${ }^{*} \mathrm{P}<0.05$ was considered a significant versus untreated cells. ${ }^{*} \mathrm{P}$-value $0.02,{ }^{* *} \mathrm{P}$-value= 0.002 (Overweight); ${ }^{* * *}$-value $=<0.001$ (Obese \pm hypertension). 


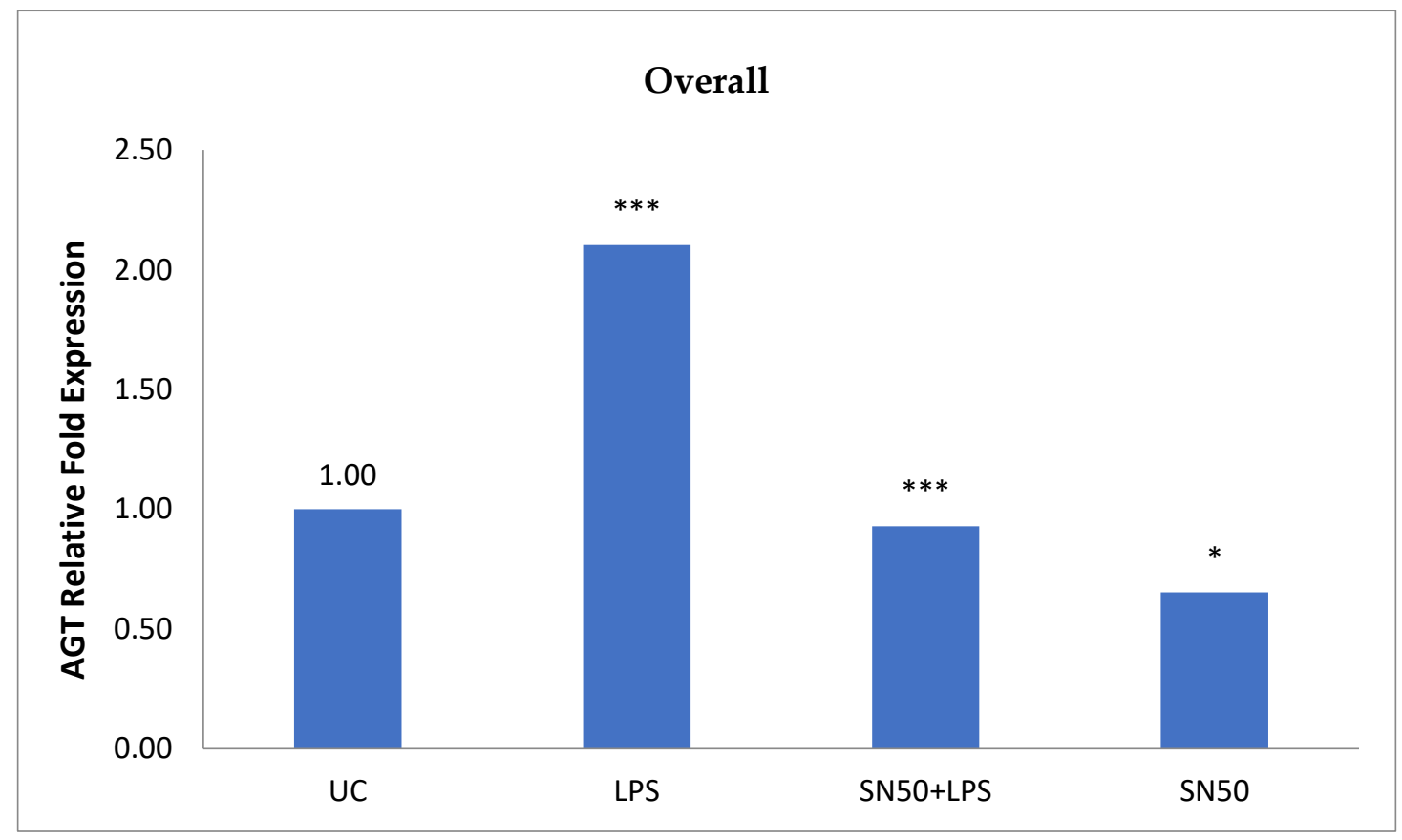

Figure 7. mRNA Expression of AGT Level in Human Cultured AbdSc adipocytes in the Combined Group Studied. Total RNA was isolated from AbdSc adipocytes treated with LPS (10 ng/ml) in the presence and absence of SN50 $(50 \mu \mathrm{g} / \mathrm{ml})$ at 12 hours incubation. Quantitative RT-PCR was performed using a premade TaqMan probe for AGT. The quantitative fold changes in mRNA expression were determined as relative to $18 \mathrm{~S}$ mRNA levels in each corresponding group and calculated using the 2$\Delta \Delta^{\mathrm{CT}}$ method. Statistical analysis was undertaken using the independent sample t-test. $\mathrm{P}<0.05$ was considered a significant versus untreated cells. ${ }^{*} \mathrm{P}$-value $=0.04,{ }^{* * *} \mathrm{P}$-value $=<0.001$.

\subsection{SN50 Reduces ANG Protein in LPS-Stimulated Adipocytes}

LPS alone slightly increase AGT protein levels compared with those in control cells. Coincubation with LPS and SN50 resulted in a slight reduction of AGT protein levels at 24 hours (Figure 8).
C
LPS
SN50+LPS

AGT

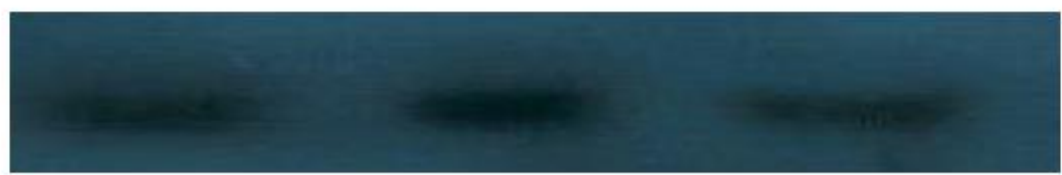

\section{B-actin}

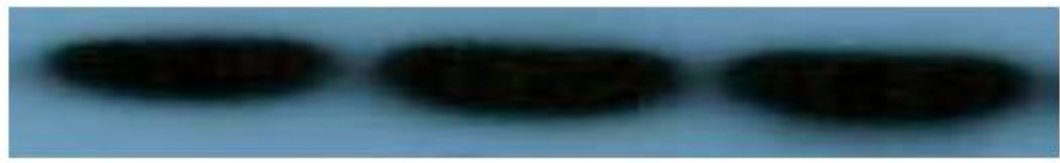

Figure 8. Angiotensinogen Antibody by Western Blot. Adipocyte cells were treated with LPS at 10 $\mathrm{ng} / \mathrm{ml}$ in the presence and absence of SN50 $(50 \mu \mathrm{g} / \mathrm{ml})$ at 24 hours incubation. Proteins (20 $\mu \mathrm{g}$ per lane) were separated by $12 \%$ SDS-PAGE and analyzed by western blotting using the anti-AGT antibody. Loading equality was controlled using antibody against the $\beta$-actin protein.

\section{Discussion}

Despite the high prevalence of obesity and hypertension in Saudi Arabia, to date, no study has examined the relationships between pro-inflammatory adipokines and BP in the obese hypertensive phenotype, as well as the role of signaling pathways in the development of hypertension in human 
adipose tissue. Furthermore, as obesity and hypertension are increasingly considered to develop through subclinical chronic inflammation, the role of the pro-inflammatory adipokines becomes increasingly more important to understand [14]. Our study, therefore, focused on the NF- $\kappa B$ pathway as one signaling pathway contributing to the upregulation of pro-inflammatory adipokines such as TNF- $\alpha$ as well as RAS components like AGT in human adipose tissue, whose secretions in adipose tissue is coordinated through NF-kB activation. Harvested and isolated abdominal subcutaneous adipose tissue is used for this work.

As adipose tissue plays an important role in the secretion of certain pro-inflammatory adipokines and activation of these adipokines is coordinated through the NF- $k B$-dependent pathway $[4,15,16,17]$. The present study, therefore, examined in vitro, the effect of NF- $\kappa B$ blocker, (SN50) on TNF- $\alpha$ secretion as well as mRNA and protein TNF- $\alpha$ and AGT expression in primary human adipocytes isolated from overweight and obese subjects with and without hypertension, and treated with 10ng/ml LPS as a potent stimulant pathogen at different concentrations and time points.

Our findings demonstrated that LPS significantly stimulates NF- $\mathrm{kB}$ activation in a concentration higher or equivalent to Jurkat cell (positive control cells) in both groups. Lipopolysaccharide also increases NF- $\mathrm{kB}$ p65 protein levels compared with those in control cells at 3 and 12 hours, and did not affect at 24 hours. In contrast, coincubation with LPS and SN50 resulted in a marked reduction in NF- $\kappa B$ p65 levels as compared with those treated only with LPS. However, SN50 alone did not affect on LPS through NF-kB activation and expression. Our findings suggest that SN50 at least in part suppresses NF-kB-mediated inflammatory pathways in adipose tissue. Another interesting finding is the relationship between NF- $\kappa B$ activation and the degree of adiposity. Our study observed a strong relationship between BMI and NF- $\mathrm{B}$ p 65 , which remained significant independent of age.

Liposaccharide is a well-preserved component of the external part of the gram-negative bacterial cell wall [18]. This molecule is recognized by the innate immune system via TLRs; a class of proteins that play a key role in the innate immune system, which recognize antigens including LPS, on monocytes/macrophages activation. Activation of TLRs (particular TLR-4) leads to translocation of NF- $\kappa B$ into the nucleus to initiate gene expression of cytokines like IL- 1, IL- 6 , and TNF- $\alpha[18,19,20]$.

As numerous studies showed that the endotoxin LPS has a potent inflammatory stimulant on cytokines secretion through NF- $\kappa B$ activation $[4,21]$, hence our present study addressed the principal activation regulatory pathways of the secretion of TNF- $\alpha$ by LPS via NF- $\kappa B$ activation. Treatment of adipocytes with $10 \mathrm{ng} / \mathrm{ml}$ LPS caused a significant increase in TNF- $\alpha$ secretion. Whereas, a significant decrease occurred in response to the presence of SN50 as compared with those cells treated with LPS at 3, 12, and 24 hours. The maximum inhibitory action of SN50 on NF- $\mathrm{kB}$ activation is obtained with a concentration of $50 \mu \mathrm{g} / \mathrm{ml}$ without causing cell death, which was observed at 12 hours after treatment. This effect was gradually decreased in both groups. In contrast, SN50 alone did not affect TNF- $\alpha$ secretion compared with control cells. Moreover, our findings observed that TNF- $\alpha$ secretion was significantly higher in the obese hypertensive than the overweight group.

Secretion of pro-inflammatory adipokines from adipose tissue has been studied by previous authors $[4,22,23]$. Adipocytes are known to secrete large quantities of IL-6 as well as non-negligible amounts of TNF- $\alpha$ compared to macrophages [22,23], and there is increasing evidence supposing that adipocytes are highly implicated in the inflammatory phenomenon associated with the development of obesity-related hypertension. However, Hoareau et al. [18] have shown that macrophages are more sensitive to LPS than adipocytes, being able to respond to $5 \mathrm{ng} / \mathrm{ml}$ of LPS more than adipocytes, which are sensitive to $50 \mathrm{ng} / \mathrm{ml}$ LPS. The number of TLR4 on the surface of the cells could in part explain these differences in response between adipocytes and macrophages [18]. The production of TNF- $\alpha$ by adipocytes may be of special importance because up to one-third of circulating TNF- $\alpha$ is secreted by adipose tissue [24]. Besides, an increase in central (visceral) adiposity confers higher metabolic risk. This increased metabolic risk is associated with subclinical inflammation.

This mechanism has been noted in numerous studies, which demonstrate that LPS can stimulate the release of pro-inflammatory cytokines such as TNF- $\alpha$ via the NF- $\kappa B$ activation $[18,21]$. They observed that TNF- $\alpha$ production in human adipocytes is dependent on the NF- $\kappa B$ pathway. Lehrke et al. [21], showed that LPS increases resistin production by inducing secretion of TNF- $\alpha$. This 
increase in resistin production can be blocked by both aspirin and rosiglitazone drugs that have a dual anti-inflammatory and insulin-sensitizing action and have been shown to antagonize NF- $\mathrm{B}$ activity. Indeed, loss of NF-kB function abolishes LPS induction of resistin [21]. In a study of adipocytes of mice, it was found that resistin caused insulin resistance and glucose intolerance [25], and the mice, who are lacking resistin have low blood glucose levels [26]. The ability of resistin to modulate glucose metabolism is associated with the activation of SOCS3, an inhibitor of insulin signaling in adipocytes [25]. To its effect on glucose metabolism, an increase in serum resistin also predicted the risk for increased both systolic and diastolic BP in patients with T2DM independently on age, gender, BMI, fasting blood glucose, and HDL-cholesterol [27].

Moreover, Zhang et al. [28] showed that resistin can predict the risk of future hypertension among non-diabetic women aged $\geq 55$ years even after adjustment for inflammatory and endothelial markers, as well as can promotes endothelial cell activation through the release of ET-1 and upregulation of VCAM-1 and ICAM-1 [29]. Besides, resistin also increases TNF- $\alpha$ and IL-6 expression in white adipose tissue [30].

As NF- $\kappa \mathrm{B}$ plays a role in the regulation of gene transcription, the present study reported this role in mRNA TNF- $\alpha$ and AGT levels of overweight and obese patients with and without hypertension at 12 hours. Treatment of AbdSc adipocytes with LPS increases mRNA TNF- $\alpha$ level twofold as compared with those in untreated cells in both groups. In contrast, the treatment of AbdSc adipocytes with LPS in the presence of SN50 cause a decrease in mRNA TNF- $\alpha$ level as compared with those in LPS-treated in overweight subjects, whereas, no significant change was observed in mRNA TNF- $\alpha$ level in obese with and without hypertension. Moreover, SN50 alone had no effect on TNF- $\alpha$ mRNA level in both groups observed. In contrast, our study demonstrated that mRNA TNF$\alpha$ level was increased 2-folds in LPS-treated as compared with control cells in the combined group, and was significantly decreased in the presence of SN50. In addition to its effect on gene expression, LPS also slightly increases the TNF- $\alpha$ protein levels as compared with those in control cells. In contrast, coincubation with LPS and SN50 resulted in a reduction of TNF- $\alpha$ protein levels at 24 hours.

Similarly, treatment of AbdSc adipocytes with LPS causes an increased mRNA AGT level 2-folds as compared with those in control cells in both groups, whereas the treatment of AbdSc adipocytes with LPS in the presence of SN50 causes a decrease in mRNA AGT level. Moreover, mRNA AGT level was increased twofold in LPS-treated and reduced in the presence of SN50 compared with LPStreated in the combined group. LPS alone also slightly increases the AGT protein levels compared with those in control cells. Coincubation with LPS and SN50 resulted in a slight reduction of AGT protein levels at 24 hours. Thus, LPS can cause an inflammatory status in adipocytes, and the inflammatory status leads to increased TNF- $\alpha$ via NF- $\kappa$ B and increased AGT and ANG II via RAS. The block of NF-kB activation by SN50 lead to a decrease in the inflammatory status, this is responsible for obesity and co-morbidities such as hypertension.

\section{Conclusion}

Our study clearly demonstrates that LPS induced activation pathway may be an integral part of the inflammatory process in white adipocytes linked to obesity and obesity-related complications. This stimulatory action seems to be mediated via the NF- $\mathrm{kB}$ activation. Thus, NF- $\mathrm{kB}$ inflammatory pathway may represent a regulator of the inflammatory processes in obesity-related hypertension. Taken together these adipokines with NF- $\mathrm{kB}$ activation may therefore represent important biomarkers to evaluate hypertension risk, as well as provide mechanistic insight into the pathogenesis of obesityrelated hypertension.

Author Contributions: Conceptualization: N.M.A., P.G.M., L.S.M.; methodology: P.G.M., R.M.S., L.S.B.; software: R.M.S., L.S.B.; tissue experiment: R.M.S., and L.S.B.; samples investigation: L.S.B., and R.M.S.; manuscript writing: P.G.M., A.A.A., N.M.A., and L.S.B.; Manuscript review: P.G.M., N.M.A., and A.A.A.

Acknowledgments: The authors are grateful to National Plan for Science and Technology (NPST grant \#08MED-603-2), Riyadh, KSA, for funding the study and the ${ }^{1}$ Chair for Biomarkers of Chronic Diseases and Obesity Research Center, KSU for technical support. Also, we are thankful to the primary care physicians and nurses 
who recruited and collected the data and tissue samples of the participants. Special thanks to Mr. Benjamin Vinodson for the statistical analysis.

Conflicts of Interest: The authors declare no conflicts of interest.

\section{References}

1. Taube, A.; Schlich, R.; Sell, H.; Eckardt, K.; Eckel, J. Inflammation and metabolic dysfunction: Links to Cardiovascular Disease. Am. J. Physiol Heart Circ. Physiol. 2012, 302, H2148-H2165. https://doi.org/10.1152/ajpheart.00907.2011.

2. Stabouli, S.; Kotsis, V.; Papamichael, C.; Constantopoulos, A.; Zakopoulos, N. Adolescent obesity is associated with high ambulatory blood pressure and increased carotid intimal medial thickness. J. Ped. 2005, 147, 651-656. https://doi.org/10.1016/j.jpeds.2005.06.008.

3. Takeshita, Y.; Takamura, T.; Ando, H.; Hamaguchi, E.; Takazakura, A.; Matsuzawa-Nagata, N.; Kaneko, S. Cross talk of tumor necrosis factor-alpha and the renin-angiotensin system in tumor necrosis factor-alphainduced plasminogen activator inhibitor-1 production from hepatocytes. Eur. J. Pharmacol. 2008, 579, 426432. https://doi.org/10.1016/j.ejphar.2007.11.016.

4. Creely, S.J.; McTernan, P.G.; Kusminski, C.M.; Fisher, M.; Da Silva, M.N.F.; Khanolkar, M.; Evans, M.; Harte, A.L.; Kumar, S. Lipopolysaccharide activates an innate immune system response in human adipose tissue in obesity and type 2 diabetes. Am. J. Physiol. Endocrinol. Metab. 2007, 292, E740-E747. https://doi.org/10.1152/ajpendo.00302.2006.

5. Kawai, T.; Akira, S. TLR signaling. Cell Death Differ. 2006, 13, 816-825. http://www.nature.com/cdd.

6. Lehrke, M.; Reilly, M.P.; Millington, S.C.; Iqbal, N.; Rader, D.J.; et al. An inflammatory cascade leading to hyperresistinemia in Humans. PloS. Med. 2004, 1(2), e45. https://doi.org/10.1371/journal.pmed.0010045.

7. Harte, A.L.; McTernan, P.G.; Chetty, R.; Coppack, S.; Katz, J.; Smith, S.; Kumar, S. Insulin-mediated upregulation of the renin-angiotensin system in human subcutaneous adipocytes is reduced by rosiglitazone. Circulation. 2005, 111, 1954-1961. https://doi.org/10.1161/01.CIR.0000161954.17870.5D.

8. Hall, G.; Hasday, J.D.; Rogers, T.; B. Regulating the regulator: NF-kappa B signaling in heart. J. Mol. Cell. 2006, 41, 580-591. https://doi.org/10.1016/j.yjmcc.2006.07.006.

9. Lin, Y.Z.; Yao, S.Y.; Veach, R.A.; Torgerson, T.R.; Hawiger, J. Inhibition of nuclear translocation of transcription factor NF-kappa B by a synthetic peptide containing a cell membrane-permeable motif and nuclear localization sequence. J. Biol. Chem. 1995, 270, 14255-14258. https://doi:10.1074/jbc.270.24.14255.

10. McTernan, P.G.; Anwar, A.; Eggo, M.C.; Barnett, A.H.; Stewart, P.M.; Kumar, S. Gender differences in the regulation of $\mathrm{P} 450$ aromatase expression and activity in human adipose tissue. Int. J. Obes. Relat. Metab. Disord. 2000, 24, 875-881. https://doi.org/10.1038/sj.ijo.0801254.

11. Renard, P.; Ernest, I.; Houbion, A.; Art, M.; Le, C.H.; Raes, M.; Remacle, J. Nucleic acids Res. 2001, 29 , e4-e21. https://doi.org/10.1093/nar/29.4.e21.

12. Bradford, M.M. A rapid and sensitive method for the quantitation of microgram quantities of protein utilizing the principle of protein-dye binding. Anal. Biochem. 1976, 72, 248-254.

13. Heller, R.A.; Schena, M.; Chai, A.; Shalon, D.; Bedilion, T.; Gilmore, J.; Woolley, D.E.; Davis, R.W. Discovery and analysis of inflammatory disease-related genes using cDNA microarrays. Proc. Natl. Acad. Sci. USA. 1997, 94, 2150-2155. https://doi.org/10.1073/pnas.94.6.2150.

14. Chamarthi, B.; Williams, G.H.; Ricchiuti, V.; Srikumar, N.; Hopkins, P.N.; Lauther, J.M.; Jeunemaitre, X.; Thomas, A. Inflammation and hypertension: the interplay of interleukin-6, dietary sodium, and the reninangiotensin system in humans. Am. J. Hypertens. 2011, 24, 1143-1148. https://doi.org/10.1038/ajh.2011.113.

15. Kern, P.A.; Ranganathan, S.; Li, C.; Wood, L.; Ranganathan, G. Adipose tissue tumor necrosis factor and interleukin-6 expression in human obesity and insulin resistance. Am. J. Physiol. Endocrinol. Metab. 2001, 280, E745-E751. https://doi.org/10.1152/ajpendo.2001.280.5.E745.

16. Vozarova, B.; Weyer, C.; Hanson, K.; Tataranni, P.A.; Bogardus, C.; Pratley, R.E. Circulating interleukin-6 in relation to adiposity, insulin action, and insulin secretion. Obes. Res. 2001, 9, 414-417. https://doi.org/10.1038/oby.2001.54.

17. Senn, J.J.; Klover, P.J.; Nowak, I.A.; Mooney, R.A. Interleukin-6 induces cellular insulin resistance in hepatocytes. Diabetes. 2002, 51, 3391-3399. https://doi.org/10.2337/diabetes.51.12.3391.

18. Hoareau, L.; Bencharif, K.; Rondeau, P.; Murumalla, R.; Ravanan, P.; Tallet, F.; Delarue, P.; Cesari, M.; Roche, R.; Festy, F. Signaling pathways involved in LPS induced TNF-alpha production in human adipocytes. Journal of Inflammation. 2010, 7, 1. 
19. Muzio, M.; Polentarutti, N.; Bosisio, D.; Manoj Kumar, P.P.; Mantovani, A. Toll-like receptor family and signalling pathway. Biochem. Soc. Trans. 2000, 28(5), 563-566. https://doi.org/10.1042/bst0280563.

20. Lin, Y.; Lee, H.; Berg, A.H.; Lisanti, M.P.; Shapiro, L.; Scherer, P.E. The lipopolysaccharide-activated tolllike receptor (TLR)-4 induces synthesis of the closely related receptor TLR-2 in adipocytes. J. Biol. Chem. 2000, 275, 24255-24263. https://www.jbc.org/content/275/32/24255.

21. Lehrke, M.; Reilly, M.P.; Millington, S.C.; Iqbal, N.; Rader, D.J.; Lazar, M.A.; An inflammatory cascade leading to hyperresistinemia in humans. PloS. Med. 2004, 1, 2:e45. https://doi.org/10.1371/journal.pmed.0010045.

22. Hoareau, L.; Ravanan, P.; Gonthier, M.P.; Delarue, P.; Goncalves, J.; Cesari M.; Festy, F.; Roche, R. Effect of PEA on LPS inflammatory action in human adipocytes. Cytokine. 2006, 34, 291-296. https://doi.org/10.1016/j.cyto.2006.06.005.

23. Bes-Houtmann, S.; Roche, R.; Hoareau, L.; Gonthier, M.P.; Festy, F.; Caillens, H.; Gasque, P.; Lefebvre d'Hellencourt, C.; Cesari, M. Presence of functional TLR2 and TLR4 on human adipocytes. Histochem. Cell. Biol. 2007, 127, 131-137. https://link.springer.com/article/10.1007\%2Fs00418-006-0230-1.

24. Cawthorn, W.P.; Sethi, J.K. TNF-alpha and adipocyte biology. FEBS Letters. 2008, 582, $117-131$. https://doi.org/10.1016/j.febslet.2007.11.051.

25. Steppan, C.M.; Bailey, S.T.; Bhat, S.; Brown, E.J.; Banerjee, R.R.; Wright, C.M.; Patel, H.R.; Ahima, R.S.; Lazar, M.A. The hormone resistin links obesity to diabetes. Nature. 2001, 409, $307-312$. https://www.nature.com/articles/35053000.

26. Banerjee, R.R.; Rangwala, S.M.; Shapiro, J.S.; Rich, A.S.; Rhoades, B.; Qi, Y.; Wang, J.; Rajala, M.W.; Pocai, A.; Scherer, P.E.; Steppan, C.M.; Ahima, R.S.; Obici, S.; Rossetti, L.; Lazar, M.A. Regulation of fasted blood glucose by resistin. Science. 2004, 303, 1195-1198. https://doi.10.1126/science.1092341.

27. Takata, Y.; Osawa, H.; Kurata, M.; Kurokawa, M.; Yamauchi, J.; Ochi, M.; Nishida, W.; Okura, T.; Higaki, J.; Makino, H. Hyperresistinemia is associated with coexistence of hypertension and type two diabetes. Hypertension. 2008, 51, 534-539. https://doi.org/10.1161/HYPERTENSIONAHA.107.103077.

28. Zhang, H.; Cui, J.; Zhang, C. Emerging role of adipokines as mediators in atherosclerosis. World J. Cardiol. 2010, 2, 370-376. https://dx.doi.org/10.4330\%2Fwjc.v2.i11.370.

29. Verma, S.; Li, S.H.; Wang, C.H.; Fedak, P.W.; Li, R.K.; Weisel, R.D.; Mickle, D.A. Resistin promotes endothelial cell activation: further evidence of adipokine-endothelial interaction. Circulation. 2003, 108(6), 736-740. https://doi.org/10.1161/01.CIR.0000084503.91330.49.

30. Rabe, K.; Lehrke, M.; Parhofer, K.G.; Broedl, U.C. Adipokines and insulin resistance. Mol. Med. 2008, 14, 741-751. https://link.springer.com/article/10.2119/2008-00058.Rabe.

(C) 2020 by the authors. Licensee MDPI, Basel, Switzerland. This article is an open access article distributed under the terms and conditions of the Creative Commons Attribution (CC BY) license (http://creativecommons.org/licenses/by/4.0/). 